\title{
Roasting soybeans in a microwave for manufacturing chocolate dragées
}

\author{
Adriana Luiza Wain Tassi ${ }^{1}$ Juliana Aparecida Correia Bento ${ }^{1}$ (D) Karen Carvalho Ferreira ${ }^{1}$ \\ Márcio Caliari $^{*}$ (D) Vera Sônia Nunes da Silva ${ }^{2}$ Maria Teresa Bertoldo Pacheco \\ Elza Iouko Ida ${ }^{3}$ Manoel Soares Soares Júnior ${ }^{1}$
}

${ }^{1}$ Universidade Federal de Goiás (UFG), 74690-900, Goiânia, Goiás, Brasil. E-mail: macaliari@ig.com.br. "Corresponding author. ${ }^{2}$ Instituto de tecnologia de alimentos de São Paulo (ITAL), Campinas, São Paulo, Brasil.

${ }^{3}$ Universidade Estadual de Londrina (UEL), Londrina, Paraná, Brasil.

\begin{abstract}
This study aimed to evaluate the effect of different microwave-roasting timeson different sizes of soybean grains with black tegument to achieve the best crunchiness, flavor, and hardness. Black soybean dragées-containing a soybean core coated with layers of chocolate (dragée) - were manufactured, and their nutritional value, microbiological risk, acceptability, and consumer-purchase intentions were verified. Flavor and crunchiness of the roasted black soybeans wereonly affected by the roasting time in the microwave, whereas the hardness was only affected by grain size. The best core of the dragéewas obtainedusing grains ofsieve size 15 (large grains) roastedin the microwave for $11 \mathrm{~min}$; this core presented higher frequencies for extremely crunchy notes (56\%), toasted flavor (61\%), and an instrumental hardness close to that of the existing commercial product $(33.17 \mathrm{~N})$. The manufactured dragées did not present resistant starch, anthocyanins, and microbiological risk, and they were sensorially accepted by the tasters (mean scores of 7.77 for texture and 8.36 for appearance on a scale of 1 to 9). Thus, roasted black soybean dragéeshave a high marketing potential from technological, nutritional, and sensorial points of view. Key words: Glycine max L., black soybean, confectionery, anthocyanins, and starch resistant.
\end{abstract}

Torração de soja em micro-ondas para desenvolvimento de drágeas de chocolate

RESUMO: Este estudo objetivou avaliar o efeito do tempo de torra no micro-ondas para diferentes tamanhos de grãos de soja tipo alimento de tegumento preto, de forma a atingir a melhor crocância, sabor e dureza, e em seguida caracterizar o seu confeito, estruturado na forma de núcleo e camadas de cobertura de chocolate (drageados), em relação ao valor nutricional, risco microbiológico, aceitabilidade e intenção de compra pelos consumidores. O sabor e a crocância da soja preta torrada foram afetados somente pelo tempo de torra em micro-ondas, enquanto a dureza somente foi afetada pela dimensão dos grãos. O melhor núcleo (selecionado) foi obtido com os grãos de peneira 15 (grãos grandes), no tempo de 11 min de torra em micro-ondas, pois apresentou maior frequência para as notas de extremamente crocante (56\%), sabor de torrado (61\%), e uma dureza instrumental próxima ao produto comercial (33,17 N). As drágeas não apresentaram amido resistente, antocianinas e risco microbiológico, e foram sensorialmente aceitas pelos provadores (scores médios de 7,77 para textura e 8,36 para aparência, em uma escala de 1 a 9). Portanto, o drageado de soja preta torrada com chocolate é viável do ponto de vista tecnológico, nutricional e sensorial, com alto potencial de comercialização.

Palavras-chave: Glicyne max L., torrefação, confeito, antocianinas e amido resistente.

\section{INTRODUCTION}

Soybean (Glycine max (L.) Merr., Fabaceae) is one of the most important crops for human and animal consumption, and it is considered a nutrient-rich food. Soybeanis a staple food in Asian cuisines and is; therefore, consumed regularly in these countries (ITO, 2014). Soybean contains a large amount of essential proteins, minerals, and phenolic compounds, such as isoflavones and anthocyanins, which are important bioactive compounds that offer health benefits because of their antioxidant properties (BELLALOUI, 2012; ASTADI 2009). Some studies have drawn associations between soybean consumption and positive effects on lung diseases
(HIRAYAMA et al., 2009), cardiovascular diseases (REBHOLZ et al., 2013), and some cancers (CHEN et al., 2014).

Among the different types of soybeans, black soybeans showed higher antioxidant activity because of the higher content of anthocyanins (XU et al., 2017; WANG et al., 2014), flavonoids, $\gamma$-tocopherol, and isoflavones (LEE et al., 2016). In addition to conferring the dark color, anthocyanin pigments are suggested as potential anti-inflammatory agents, and they are characterized as functional foods. Thus, their use may help benefit the prevention of diabetes and obesity (ZILIC et al., 2013). Black soybeans are used in foods such as soymilk, tofu, soy sauce, soybean shoots; the sale of these foods has 
increased owing to increasing consumer awareness about black soybeans as a healthy food ingredient (LEE et al., 2009).

Heat treatment improves the nutritional quality of soybean because heat eliminates antinutritional compounds; moreover, it removes the characteristic "soy" flavor of the soybean attributed to the action of lipoxygenases (SÁ et al., 2006). According to SILVA \& FERNANDES (2011), roasting is a heat treatment that can improve protein digestibility, inactivate antinutrients, form aromatic compounds, and cause browning and water evaporation.

Food processing involves a variety of techniques including dragéeing. Dragéesand other coated products are becoming increasingly important in the snack, candy, and chocolate industries because they allow combination of different cores and coverings, and they have varying contents, presentations, textures, and flavors, in addition to other factors. Dragéeing is defined as the controlled thickening of a core through application of successive layers of sugar solutions or other ingredients via sprinklers with or without air injection for drying (PEREIRA, 2010; GESCHWINDNER \& DROUVEN, 2009).

There is a lack of information about roasting soybeans in microwaves and on draining soybeans with chocolate; therefore, the objective of this research was to study the effect of roasting time in a microwave on integuments of three sizes of black soybean to achieve the best crunchiness, flavor, and hardness of the dragée core, and to verify the nutritional value and the functional, microbiological, and sensorial qualities of dragée consisting of chocolate-coated soybean.

\section{MATERIALS AND METHODS}

\section{Materials}

Soybean seeds with black integuments (DF 06-81-1) were donated by the Agricultural Research Company of Minas Gerais (Epamig). They were planted and cultivated in the Agronomy School of the Federal University of Goiás (UFG) in a conventional system, harvested, and then used in this study. Grains were harvested manually and used in the production of dragées; they were classified by size: small grains, represented by the weight of 100 (hundred) seeds (WHS) less than $10 \mathrm{~g}$ (sieve 11: Sv11); medium grains, with WHS between 10 and 19 g (sieve 14: Sv14), and large grains, with WHS equal to or greater than $20 \mathrm{~g}$ (sieve15: Sv15). Dirt were separated manually and grains were stored in a cold chamber $\left(10 \pm 1^{\circ} \mathrm{C}\right)$ in cotton cloth bags.

\section{Roasting grains in the microwave}

After preliminary tests under different roasting conditions, a completely randomized design with a factorial scheme of $3 \times 5$ was chosen, which totaled 15 treatments with 3 grain sizes (sieves 11, 14 , and 15$), 5$ toasting times $(7,8,9,10$, and $11 \mathrm{~min})$, and 4 repetitions. Grain bleaching was performed before the roast: grains were placed in boiling water (ratio: 1:5) for $5 \mathrm{~min}$, immediately drained, and washed in cold water for approximately $1 \mathrm{~min}$. Then, the grains were spread on a glass refractory (diameter: $25.5 \mathrm{~cm}$; thickness: $0.5 \mathrm{~cm}$ ) and roasted in conventional microwave ovens (Panasonic, NN-ST 652WRUK220V, São Paulo, Brazil) with maximum power $(100 \%)$, stirring every $1 \mathrm{~min}$. At the end of the roast, the samples were maintained at $25{ }^{\circ} \mathrm{C}$ for cooling, and they were packed in lowdensity polyethylene (LDPE) bags. Weight loss of the soybean grains was calculated for each repetition using the weight difference before and after the roasting process.

\section{Instrumental hardness}

Instrumental hardness was measured using the TA-XTPlus Texturometer(Texture Analyser, TAXT Plus, Stable Micro Systems, Surrey, England)velocities of $1.0 \mathrm{~mm} \mathrm{~s}^{-1}$ (pre-test), $0.5 \mathrm{~mm} \mathrm{~s}^{-1}$ (during test), and $2.0 \mathrm{~mm} \mathrm{~s}^{-1}$ (post-test), an average height of $15 \mathrm{~mm}$ form the probe to the sample, and blade and guillotine geometries - at room temperature in 10 readings per repetition. Instrumental texture analysis was performed on samples of roasted soybeans, chocolate dragées with soybeans, and commercial products (roasted peanuts covered with chocolate) to draw comparisons and select the best grains for dragéeing.

\section{Flavor and crunch of roasted soybeans}

Six participants (females aged between 24 to 36 years) were selected and trained for the sensory analysis; all participants were consumers of similar products. The test was performed in a sensory analysis laboratory, in individual cabins with white light; the test results comprised the evaluation provided by the tasters regarding the roasted soybeans samples under each treatment in terms of taste and crunchiness, using scales of 1 to 5; these scales were established during the training sessions (STONE \& SIDEL, 2004). The scale defined for crunchiness varied between slightly crunchy (1) to extremely crunchy (5), and the scale 
for flavor ranged from strong taste of raw soybeans (1) to burned soybeans (5). The experiment was approved by the Ethics and Research Committee of UFG, under protocol number 041/13 CEP-UFG.

\section{Dragéeing roasted soybeans (selected core) with chocolate}

One of the treatments in the roasting trial was dragéeing, and it considered the flavor, crunch, and similarity with respect to the instrumental hardness of similar commercial peanut products. The selected roasted soybeans were dragéed in Cereal Chocotec of the Institute of Food Technology of São Paulo (ITAL), according to the methodology described by FADINI \&QUEIROZ (2014). The pilot dragline was used (Incal, JAA-110-E, São Paulo, Brazil). Acacia gum (40\%) and a cocoa-sugar mixture (1:1) were used by applying two different loads: first, $20 \mathrm{ml}$ of gum and $60 \mathrm{~g}$ of the mixture, and second, $20 \mathrm{ml}$ of gum and $53 \mathrm{~g}$ of the mixture. Ten layers of semi-sweet milk chocolate were applied (130 g per application) using a sprinkler. At the end of processing, the dragées were packed in an LDPE film and sealed. The yield of the dragées was estimated by the weight difference before and after dragéeing.

\section{Nutritional characterization of soybeans in nature and in dragées}

Values of moisture, ash, protein, lipids, and carbohydrates contents were determined via three replications according to the AOAC (2012). Resistant starch was determined as per the methods suggested in AOAC (2005) and GONI et al. (1996). Moisture content was determined by oven drying with air circulation at $105{ }^{\circ} \mathrm{C}$ until a constant weight was achieved; ash content was obtained by weighing the soybean after incineration in a muffle oven at $550{ }^{\circ} \mathrm{C}$; the nitrogen content was determined by the Kjeldahl method considering 5.71 as conversion factor for the calculation of the crude protein of soybean grains and 6.25 for the final product; the total lipid content was determined via hot extraction with petroleum ether (pa) using Soxhlet extraction; and the carbohydrate content was calculated by difference, according to equation 1. The total energy value was defined following Atwater conversion values, where available carbohydrate and protein contents are multiplied by 4 , and lipids by 9 , and the products are summated to obtain the total energy value (MERRILL \& WATT, 1973). All analyses were performed in triplicate, and the values are expressed in $\mathrm{g} 100 \mathrm{~g}^{-1}$ on a dry basis, except for moisture content.

(Eq. 1):
Carbohydrate $(\%)=100-($ moisture + ash + lipid + protein $)$ Anthocyanin content was determined according to method described in TEIXEIRA, et al. (2008) and expressed in $\mathrm{mg} 100 \mathrm{~g}^{-1}$. Microbiological analyses were carried out according to the methods established by the American Public Health Association (APHA, 2001) to determine the presence of Salmonella spp. in $25 \mathrm{~g}$ of the sample and count thermotolerant coliforms at $45^{\circ} \mathrm{C}$. All analyses were performed in triplicate.

\section{Sensory acceptance}

Sensorial acceptance of the dragée, which is based on its characteristics such as instrumental hardness, flavor, and crunchiness, was determined for the attributes of aroma, flavor, texture, and appearance using a 9-point hedonic scale, with the extremes involving terms "extremely liked" and "extremely disliked" (STONE\& SIDEL, 2004). Sensory analysis was performed by 58 untrained tasters (male and female; mean age: 25 years) who were consumers of similar products. The tests were performed at a sensory analysis laboratory, inside individual booths with red light to avoid the influence of the color of the product on the taste and crunchiness responses. For the appearance attribute, the sample was evaluated under natural light (white), and the sample was placed in a disposable white dish (25 g portion) without temperature control $\left(25^{\circ} \mathrm{C}\right)$. The acceptance test was performed after receiving signed informed consent forms from the tasters. The project was approved by the UFG Ethics and Research Committee under protocol number 041/13.

\section{Statistical analysis}

The obtained data were submitted for the analysis of variance (Factorial ANOVA), and the means were compared using the Tukey test. Descriptive statistics, such as the calculation of percentage differences and frequency distribution diagrams were also used.

\section{RESULTS AND DISCUSSION}

Sensory taste, crunchiness, and instrumental hardness of roasted black soybeans

Taste and crunchiness are important attributes for the acceptability of soybeans, which need to be crispy and free from a burnt taste or a raw soy flavor for consumer acceptability. Taste of the raw soybean, denominated "beany flavor," originates from the association of short chain carbonyl compounds with the protein fraction, which 
is catalyzed by lipoxygenase enzymes (LI et al., 2008; SHI et al., 2015). In the process of roasting, raw grains are heated in a controlled manner so that a series of exothermic reactions responsible for the degradation of several compounds can be triggered; this results in the formation of the desired flavor and aroma, without such reactions reaching the point at which carbonization begin and results in a burnt flavor (SHARMA \&GUJRAL, 2011).

Evaluation of the sensory panel indicated that the flavor of the roasted black soybean was affected only by the roasting time in the microwave $(p<0.05)$ for grains from Sv11 and Sv14, and it did not considerably affect the sensorial evaluation of the Sv15 grains (Table 1). Regardless of the grain size, a roasting time of $7 \mathrm{~min}$ resulted in soybean flavors ranging from slightly raw to strongly raw (notes 2 and 1, respectively) (Figure 1). The best frequencies of flavor notes were obtained between roasting times of 9 and $11 \mathrm{~min}$, where more than $50 \%$ of the flavor notes were between toasted soybeans (note 3 ) and slightly burned soybeans (note 4). For a roasting time of $11 \mathrm{~min}$, the taste of the raw soybean was not observed (Figure 1).

In the sensorial evaluation of the crunchiness of the roasted black soybeans, a significant difference was observed for different roasting times $(p<0.01)$ only for grains Sv14 (Table 1). Grains roasted with roasting times between 7 and 9 min presented grades varying from non-crunchy to moderately crunchy $(>60 \%)$. Conversely, most tasters $(56 \%)$ evaluated beans roasted for $11 \mathrm{~min}$ as extremely crunchy (Figure 2). Crunchiness was negatively affected by the moisture content in the grain; higher the roasting time, the lower is the moisture; and consequently, higher is the crunchiness.

Texture of the roasted soybean was significantly affected only by grain size $(p<0.01)$ at roasting times of 9 and $11 \mathrm{~min}$; the average hardness as a function of time varied by $34.8 \%$ (Table 1 ). After $11 \mathrm{~min}$ of roasting, the lowest hardness was obtained in grains from Sv11 (24.43 N) (Figure 3). This is because water is removed from bleached grains when they are roasted, which makes the grains more friable; the free water is eliminated by making the grains more susceptible to breakage (JOGIHALLI et al., 2017). This higher susceptibility to breaking caused by the roasting level has an inverse relationship with the water content of the grain, because the higher the roasting time, the lower is the value of water content (OLIVEIRA et al., 2014).

Hardness of the soybean (Sv11) toasted for $11 \mathrm{~min}$ (used in the validation test) was similar to that of the peanut core in the commercial chocolate dragée (Table 1). However, hardness of the black soybeans (Sv15) toasted for $11 \mathrm{~min}$ was similar to that of commercial roasted peanuts, and thus, it was thus selected for manufacturing chocolate-covered soybeans. Further, the larger size of the soybean results in a larger product; and consequently, this has a greater commercial appeal because of its appearance.

Yield and instrumental hardness of soybeans with chocolate coating

The analysis of mass balance in the production process of the dragées indicated that when roasting the soybean grains, a mass loss of $22.1 \%$ occurred as the roasting process leads to the loss

Table 1 - Means of the notes of flavor, crunchiness, and hardness of the soybean with black integument, food type, treated ina microwave oven with functions of roasting timeandgrain size.

\begin{tabular}{|c|c|c|c|c|c|c|c|c|c|}
\hline \multirow[t]{2}{*}{ Time } & \multicolumn{3}{|c|}{------------------Flavor----------------- } & \multicolumn{3}{|c|}{--------------Crunchiness------------ } & \multicolumn{3}{|c|}{--------------Hardness (N)------------ } \\
\hline & Sv11 & Sv14 & Sv15 & Sv11 & Sv14 & Sv15 & Sv11 & Sv14 & Sv15 \\
\hline 7 & $1.8^{\mathrm{Ba}}$ & $1.2^{\mathrm{Ca}}$ & $2.2^{\mathrm{Aa}}$ & $2.2^{\mathrm{Aa}}$ & $2.8^{\mathrm{ABa}}$ & $3.0^{\mathrm{Aa}}$ & $33.46^{\mathrm{Aa}}$ & $43.97^{\mathrm{Aa}}$ & $46.81^{\mathrm{Aa}}$ \\
\hline 8 & $2.7^{\mathrm{ABa}}$ & $2.0^{\mathrm{BCa}}$ & $2.2^{\mathrm{Aa}}$ & $1.8^{\mathrm{Aa}}$ & $1.8^{\mathrm{Ba}}$ & $2.5^{\mathrm{Aa}}$ & $34.57^{\mathrm{Aa}}$ & $37.86^{\mathrm{Aa}}$ & $46.54^{\mathrm{Aa}}$ \\
\hline 9 & $3.7^{\mathrm{ABa}}$ & $3.5^{\mathrm{ABa}}$ & $3.2^{\mathrm{Aa}}$ & $2.3^{\mathrm{Aa}}$ & $2.8^{\mathrm{ABa}}$ & $2.7^{\mathrm{Aa}}$ & $36.27^{\mathrm{Ab}}$ & $34.43^{\mathrm{Ab}}$ & $46.74^{\mathrm{Aa}}$ \\
\hline 10 & $3.3^{\mathrm{ABa}}$ & $3.7^{\mathrm{Aa}}$ & $3.8^{\mathrm{Aa}}$ & $1.8^{\mathrm{Ab}}$ & $4.2^{\mathrm{Aa}}$ & $3.0^{\text {Aab }}$ & $32.22^{\mathrm{Aa}}$ & $37.67^{\mathrm{Aa}}$ & $35.03^{\mathrm{Aa}}$ \\
\hline 11 & $4.0^{\mathrm{Aa}}$ & $3.7^{\mathrm{Aa}}$ & $3.7^{\mathrm{Aa}}$ & $3.7^{\mathrm{Aa}}$ & $4.0^{\mathrm{Aa}}$ & $4.5^{\mathrm{Aa}}$ & $24.43^{\mathrm{Ab}}$ & $34.55^{\mathrm{Aa}}$ & $33.17^{\text {Aab }}$ \\
\hline Means & $3.1^{\mathrm{a}}$ & $2.8^{\mathrm{a}}$ & $3.0^{\mathrm{a}}$ & $2.4^{\mathrm{b}}$ & $3.1^{\mathrm{a}}$ & $3.1^{\mathrm{a}}$ & $32.19^{\mathrm{b}}$ & $37.70^{\mathrm{a}}$ & $41.66^{\mathrm{a}}$ \\
\hline
\end{tabular}

Means followed by the same capital letter in the column, and lowercase in the row (by parameter evaluated) do not differ among themselves by the Tukey test at $5 \%$ (notes scale from 1 to 5 , where for flavor/crunchy, respectively: 1 : heavily raw soybean/not crunchy soybean; 2 : slightly crunchy/slightly crunchy soybeans; 3 : toasted/moderately crunchy soybeans; 4 : slightly burnt/ very crunchy soybeans; and 5: burnt/extremely crunchy soybeans). 


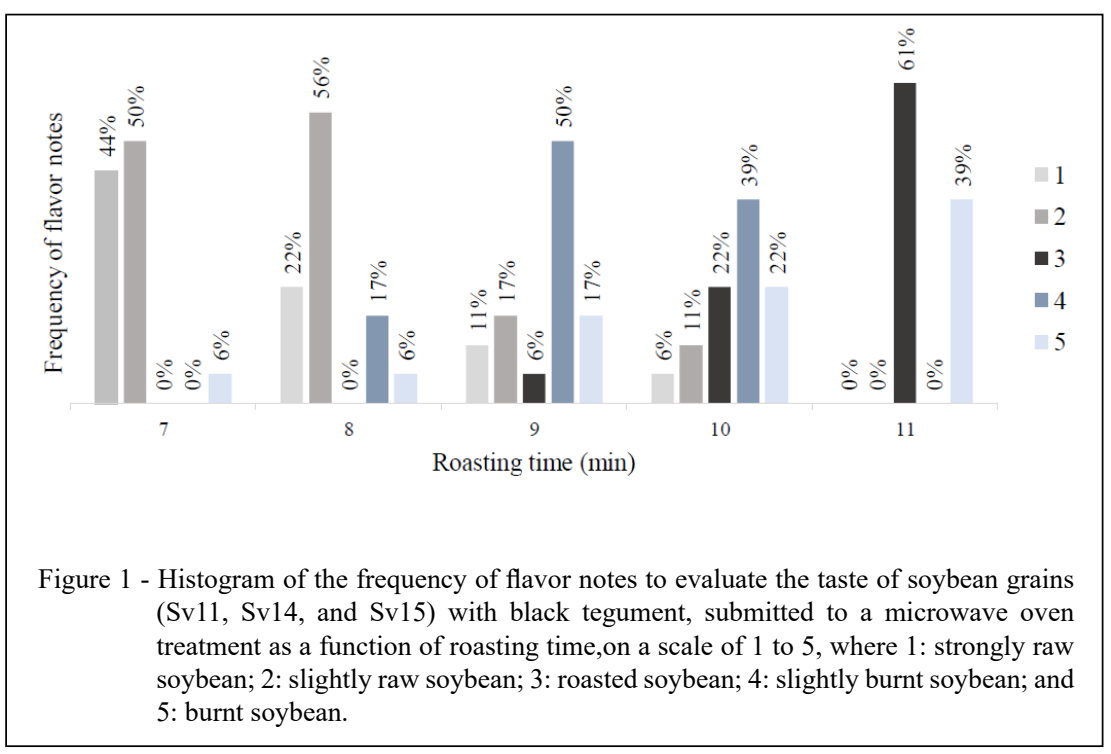

of moisture content (OLIVEIRA et al., 2014), with consequent loss of mass. Weight gain after chocolate is sprinkled was $132.8 \%$ in relation to the soya beans in nature, with $555 \mathrm{~g}$ of roasted soybeans yielding $1030.76 \mathrm{~g}$ of chocolate dragée in each batch; i.e., almost double the mass of the roasted beans.

Hardness of the chocolate black soybean dragée $(42.38 \mathrm{~N})$ was $47.7 \%$ lower than that of the commercial chocolate peanut $(62.61 \mathrm{~N})$ dragée (Table 2). This variation can be attributed to the quality of the ingredients used in the dragée cover and the dragéeing method employed. However, the hardness of the experimental dragée was $14.44 \%$ higher than that of the commercial salted roasted peanut (37.03 N) (Table 2). The chocolate covered soybeans are softer than the commercial peanut and slightly harder than the commercial salted roasted peanuts, which are widely consumed by Brazilians , and they have a higher volume than traditional chocolate peanut butter, whose coverage makes it very hard. Thus, the

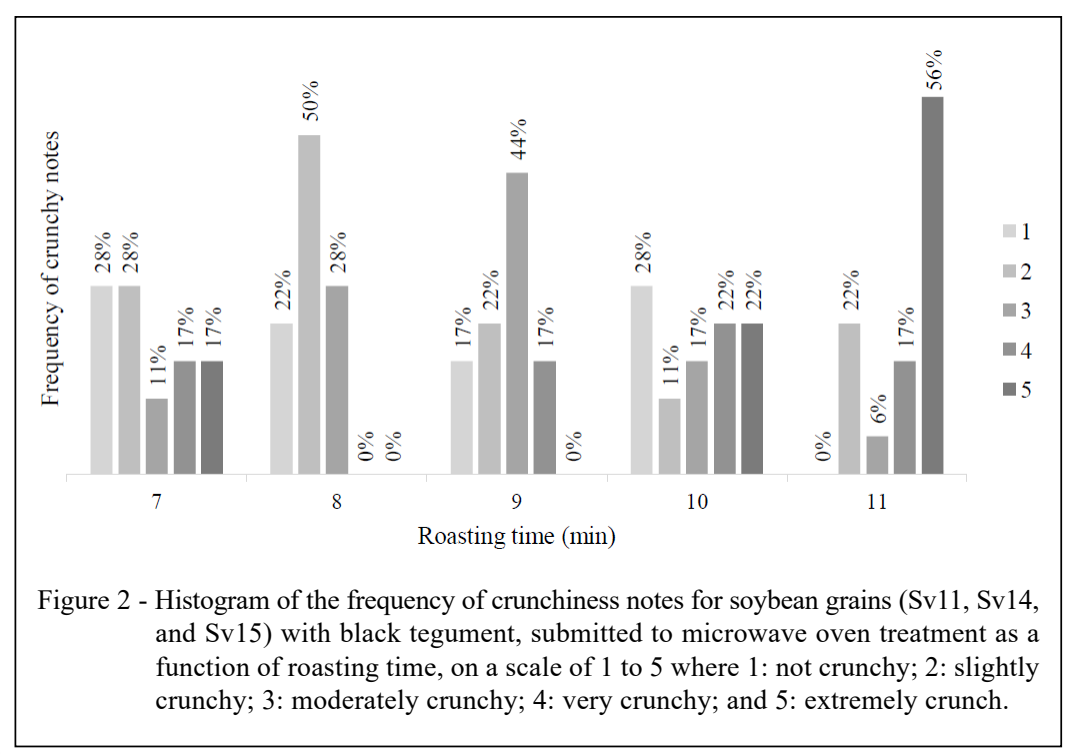

Ciência Rural, v.49, n.10, 2019. 


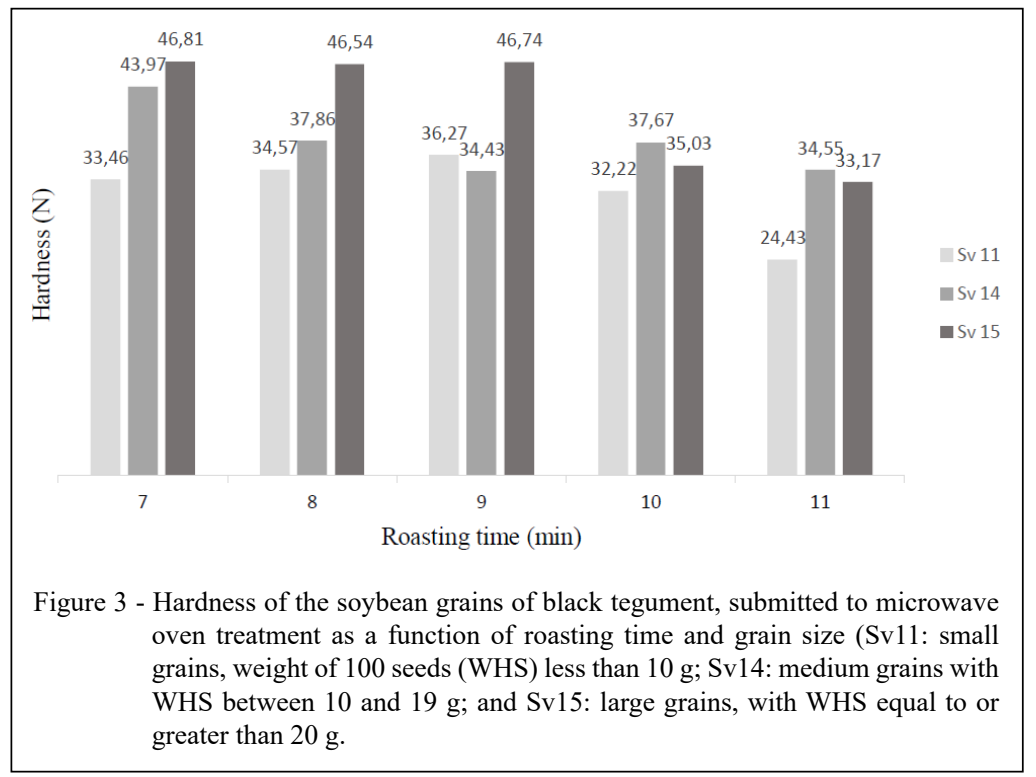

hardness standard for the development of the new dragée was not the commercial peanut product with chocolate, but an intermediate value between this and the commercial salted roasted peanut. Furthermore, owing to the high variation in the hardness observed in the standard deviations (Table 2), it was preferred to establish a lower average hardness than the traditional commercial product of chocolate peanuts.

Centesimal composition, anthocyanins, and resistant starch

Moisture, ash, and protein contents of the soybean dragée were lower than those of soybean found in nature, with the moisture content being five times lower (Table 3). In foods with a water

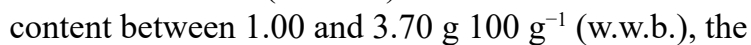
aggregation of water in the roasted grain structure is at the monolayer level, with the water molecules being strongly adsorbed at specific locations of the product, characterizing the product with low water activity (OLIVEIRA et al., 2014). This characteristic makes the product stable in terms of microbiological degradation (SYAMALADEVI et al., 2016).

There was a reduction in the ash $(43.30 \%)$ and protein contents $(41.48 \%)$, and an increase in the lipid $(52.63 \%)$ and carbohydrate $(30.50 \%)$ contents in the final product (dragées) compared with the soybean grain in nature (Table 3). This difference

Table 2 - Hardness (N) of black soybeans (nucleus) roasted in microwave, black soybeans drained with chocolate, and commercial peanut patterns (roasted, peanut core with chocolate, and peanut with chocolate).

\begin{tabular}{lccc}
\hline Product & Hardness (N) & Standard deviation & Coefficient of variation (\%) \\
\hline Roasted black soybeans (Sv 15.11 min) & 33.17 & 10.41 & 28.76 \\
Roasted black soybeans (validation)* & 28.91 & 6.85 & 23.71 \\
Black soybeans drained with chocolate & 42.38 & 7.20 & 16.99 \\
Commercial salted roasted peanuts & 37.03 & 6.35 & 17.15 \\
Peanut core of commercial chocolate dragée & 27.62 & 4.07 & 14.75 \\
Peanut butter with commercial chocolate & 62.61 & 14.98 & 23.93 \\
\hline
\end{tabular}

*Repetition of treatment for method validation. 


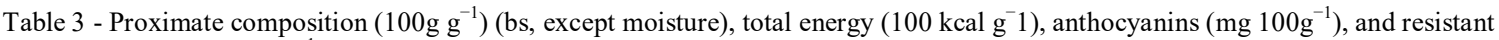

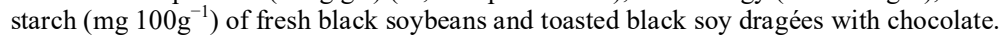

\begin{tabular}{lcc}
\hline Component & Black soya bean & Black soybean dragée \\
\hline Moisture & $10.59+0.02(0.19)$ & $2.02+0.14(6.93)$ \\
Ashes & $7.92+0.36(4.54)$ & $4.49+0.04(0.89)$ \\
Lipids & $15.03+0.07(0.47)$ & $22.94+0.89(3.88)$ \\
Protein & $31.05+0.32(1.03)$ & $16.18+0.67(4.14)$ \\
Carbohydrates & 46.00 & 56.39 \\
Total energy value & 396.52 & 486.72 \\
Anthocyanins & $7.95+0.05(0.63)$ & ND<2.00 \\
Resistant starch & ND & ND \\
\hline
\end{tabular}

*Mean followed by standard deviation and coefficient of variation.

is attributed to the incorporation of milk chocolate and a bitter medium, which contains lower levels of

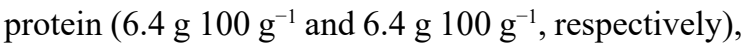
high lipid contents (31.6 g $100 \mathrm{~g}^{-1}$ and $28.0 \mathrm{~g} 100$ $\mathrm{g}^{-1}$, respectively) (GAROTO, 2018; ANDRADE et al., 2010; HUANG, et al., 2008), and to the sucrose used in the coating formulation and the sugars present in the composition of the chocolate, which affect the carbohydrate content after dragéeing. Therefore, the addition of chocolate and sugar to soybeans resulted in a product with a higher energy value than the raw soybean (Table 3 ).

According to the Brazilian ministry of health (BRASIL, 2012), a prepared food is considered a source of protein when it's protein content is below $6 \mathrm{~g} 100 \mathrm{~g}^{-1}$ or as a source of high protein when it's

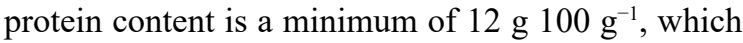
classifies the black soybeans with chocolate as a high protein product (Table 3). Black soybeans covered with chocolate (a portion of $25 \mathrm{~g}$ )(about $121 \mathrm{kcal}$ ) represent $6 \%$ of the daily reference values of a 2000 kcal per day diet, which can be included as part of a snack or dessert.

The heat treatment contributed to the degradation of anthocyanins because it was reported only in the raw soya beans (Table 3). Bleaching and roasting stages of the grains may have influenced the loss of these pigments, probably because they are water soluble and unstable at high temperatures (WANG et al., 2014). In addition, anthocyanin molecules can be degraded under certain conditions of unfavorable $\mathrm{pH}$, temperature, and oxygen concentration (WANG \& XU, 2007). ESTEVES et al. (2015) compared anthocyanin content in raw black soybean and extracts from whole grain and ground grain, with and without pasteurization, and verified that the black soybean water extract with the highest content of anthocyanins was obtained from $\left(53.94 \mathrm{mg} 100 \mathrm{~g}^{-1}\right)$; this showed a reduction of only $17.8 \%$ of the anthocyanin content in relation to the concentration found in the raw material $(65.58 \mathrm{mg}$ $\left.100 \mathrm{~g}^{-1}\right)$. The same extract, after pasteurization, showed a reduction of $27.7 \%$ of anthocyanins, confirming the influence of high temperatures on the degradation of anthocyanins. It should be noted that the roasting process reaches temperatures much higher than those of a pasteurization process, which may favor greater degradation of the anthocyanins present in the tegument of the roasted black soybean. Further, other causes of reduction in the anthocyanin content are the dilution effect achieved by the addition of the ingredients used to cover the dragée, and the limitation in the detection and quantification of the analytical method used to determine anthocyanin levels.

Presence of resistant starch (Table 3) was not detected in the black soybean grains with and without a chocolate coating. Resistant starch is the fraction of the starch that is unaffected by digestive enzymes, presenting a behavior similar to that of a dietary fiber, and it can be reported in some legumes (green peas, beans, green bananas, potatoes, etc.). However, chemical compositions may vary with the cultivar, development conditions, maturation, and processing (POLESI, 2011, MULINACI, 2008). As for the soybean, JEONG et al. (2010) reported that soybeans contain less than $1 \mathrm{~g} 100$ $\mathrm{g}^{-1}$ of starch and little is known about the genetic 
variation of resistant starch content; however, when evaluating a collection of germ plasm, they found 34 cultivars with high starch content ( 2 to $7 \%$ ). Based on this background, we suggested the conduction of further investigations on starch and resistant starch contents in black soybeans.

\section{Microbiological risk and sensory acceptance}

Chocolate-covered toasted soybean preparation followed microbiological standards established by Resolution RDC No12 of January 2001 (BRASIL, 2001): Coliforms at $45{ }^{\circ} \mathrm{C}$ presented less than $10 \mathrm{CFU} \mathrm{g}^{-1}$ and Salmonella spp. presente dabsentin the $25 \mathrm{~g}$ portion, thus indicating a microbiologically stable and safe product for consumption. This proves that the product was prepared following the rules of good manufacturing practices.

In general, toasted black soybeans sprinkled with chocolate presented good sensorial acceptance, and for the attributes of appearance and aroma, the average score obtained was between 8 and 9 (I liked it very much and liked it extremely) (Table 4).

Minimum scores for appearance, aroma, and flavor were 7 , and the percentage of tasters who scored 9 were $53.5 \%, 44.8 \%$, and $25.8 \%$, respectively. These results demonstrated that the manufactured product had a great appearance and aroma (Figure 4), and the soybean flavor was very discreet; this is important because Brazilian consumers are not used to the taste of the soybean because it is not part of their daily diets and due to cultural difficulties in accepting a different palate. The mild taste of this lineage is caused by improved characteristics such as absence or low content of lipoxygenases. For the texture of the dragée, $88 \%$ of the tasters graded it between 7 and 9 (I liked it slightly and liked it extremely, respectively), which indicates that the choice of $11 \mathrm{~min}$ as the roasting time for the black soybean was successful.

The purchase intention of consumers for roasted soybeans covered with chocolate was between "possibly buy" and "certainly buy," with an average grade of $4.26 \pm 0.9$, on a scale of 1 to 5 , where grade 1 is "certainly would not buy" and 5 is "would certainly buy."These results showed that the roasted black soybeans were well accepted by young tasters, who would certainly buy the product, even if they did not have a habit of consuming soybean, indicatingthat it is possible to produce soy products that will gain high acceptability in the consumer market.

\section{CONCLUSION}

Flavor and crunchiness of the roasted black soybeans were only affected by the roasting time in the microwave, and the hardness was only affected by grain size. For preparing the dragée, grains from Sv15 (larger grains) were selected and roastedfor $11 \mathrm{~min}$. Roasted black soybeans coated with chocolate showed significant levels of proteins, lipids, carbohydrates, and energy value, and an absence of resistant starch, anthocyanins, and microbiological risk; further, they were sensorially accepted by the tasters. It was, thus, concluded that roasted black soybeans coated with chocolate have a high marketing potential from technological, nutritional, and sensorial points of views.

Table 4 - Mean scores for appearance, texture, flavor, and aroma of roasted black soybeans and dragées with chocolate.

\begin{tabular}{lccc}
\hline Attribute & Mean & Standard deviation & Coefficient of variation (\%) \\
\hline Appearance & 8.38 & 0.77 & 9.13 \\
Texture & 7.55 & 1.37 & 18.11 \\
Flavor & 7.92 & 0.81 & 10.16 \\
Aroma & 8.26 & 0.78 & 9.49 \\
\hline
\end{tabular}



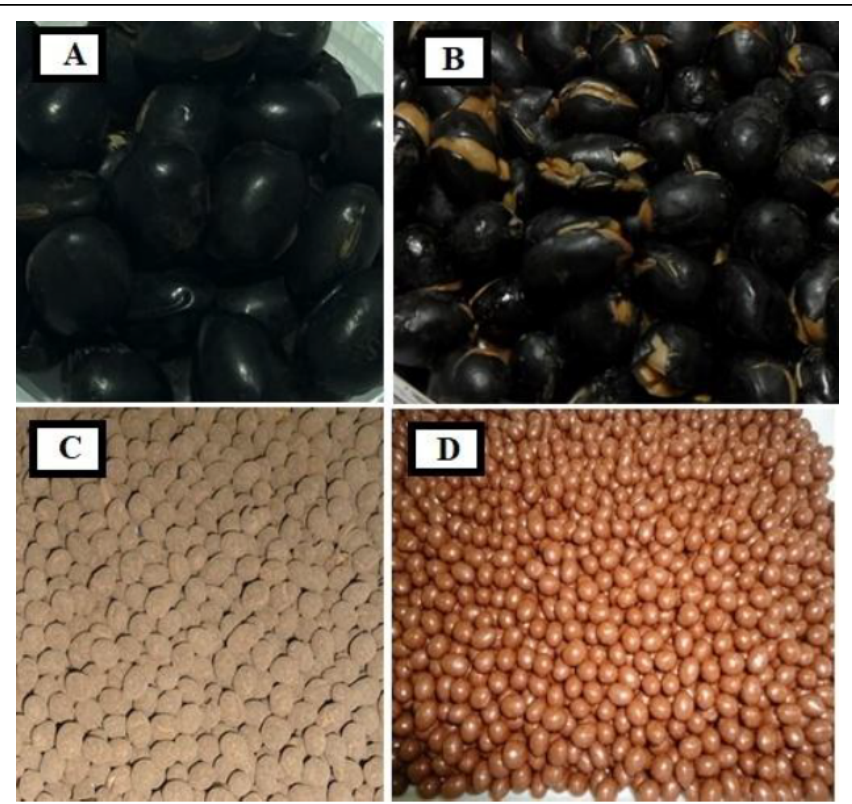

Figure 4 - Appearance of the soybeans in(A)nature, (B) roasted, (C) sealed, and (D) chocolate dragées.

\section{ACKNOWLEDGEMENTS}

The authorsthank the Coordenação de Aperfeiçoamento de Pessoal de Nível Superior (CAPES), Brasil for their scholarship support.

\section{DECLARATION OF CONFLICT OF INTERESTS}

The authors declare no conflict of interest. The founding sponsors had no role in the design of the study; in the collection, analyses, or interpretation of data; in the writing of the manuscript, and in the decision to publish the results.

\section{AUTHORS' CONTRIBUTIONS}

All authors contributed equally for the conception and writing of the manuscript. All authors critically revised the manuscript and approved of the final version.

\section{REFERENCES}

ANDRADE, G. F. et al. Appropriate heat treatment improves the nutritional quality of soybean meal made from new cultivars for human consumption.. Revista do Instituto Adolfo Lutz, v.69, p.537-544, 2010. Available from: <periodicos.ses.sp.bvs.br/pdf/ rial/v69n4/v69n4a15.pdf>. Accessed: Jun. 18, 2015.

AOAC. Association of official Analytical Chemistry. Official methods of analysis of the association of official analytical chemists. HORTWITZ, W. (Ed.). Resistant starch in starch and plant materials, Enzymatic Digestion, Final Action 2005. Gaithersburg, Maryland, $18^{\text {th }}$ ed., AOAC 2005. Current Through Revision 3, 2010, cap. 45.4.16, met 2002.02, p.129-131.

AOAC. Association of Official Analytical Chemistry. Official methods of analysis. $19^{\text {th }} \mathrm{ed}$. Gaithersburg, 2012. 3000p.

APHA. AMERICAN PUBLIC HEALTH ASSOCIATION (APHA). Compendium of methods for the microbiological examination of foods. 4. ed. Washington, DC: APHA, 2001.

ASTADI, I. R. et al. In vitro antioxidant activity of anthocyanins of black soybean seed coat in human low density lipoprotein (LDL). Food Chemistry, v.112, p.659-663, 2009. Available from: <http:// dx.doi.org/10.1016/j.foodchem.2008.06.034>. Accessed: May. 16, 2017. doi: 10.1016/j.foodchem.2008.06.034.

BELLALOUI, N. Soybean seed phenol, lignin, and isoflavones and sugars composition altered by foliar boron application in soybean under water stress. Food and Nutrition Sciences, v. 3, p. 579-590, 2012. Available from: $<$ http://dx.doi.org/10.4236/fns.2012.34080>. Acessed: May. 16, 2017. doi: 10.4236/fns.2012.34080.

BRASIL. Ministério da Saúde. Agência Nacional de Vigilância Sanitária. Resolução RDC $\mathrm{n}^{\circ} 54$, de 12 de novembro de 2012. Technical Regulationon Complementary Nutrition Information. Available from: $<$ http://portal.anvisa.gov.br/ documents/\%2033880/2568070/rdc0054 12 11 2012.pdf/ c5ac23fd-974e-4f2c-9fbc-48f7e0a31864/>. Accessed: May, $16,2019$. 
BRASIL. Ministério da Saúde. Agência Nacional de Vigilância Sanitária. Resolution RDC $\mathrm{n}^{\circ} 12$, of 2001 jan 02 nd de 2001. Technical regulation on food microbiological standards. Available from: <http://portal.anvisa.gov.br/wps/wcm/connect/ a 47bab8047458b909541d53fbc4c6735/RDC_12_2001. pdf?MOD=AJPERES $>$. Accessed: Sep. 07, 2017.

CHEN, M. N. et al. Association between soy isoflavone intake and breast cancer risk for pre- and post-menopausal women: A meta-snalysis of epidemiological studies. PloS One, v.9, p.110, 2014. Available from: <http://dx.doi.org/10.1371/journal. pone.0089288>. Accessed: May, 10, 2017. doi:10.1371/journal. pone. 0089288 .

ESTEVES, T. C. F. et al. Influence of black soybean grinding on water-soluble extracts of anthocyanin-rich soybean. In: CONGRESSO BRASILEIRO DE SOJA:MERCOSOJA, 7; MERCOSOJA, 2015, Florianópolis. Anais... Londrina: Embrapa Soja, 2015, work28. 1 CD-ROM. Available from: <https://www. alice.cnptia.embrapa.br/alice/bitstream/doc/1018901/1/2015Cong ressoBrasileiroSojap28.pdf>. Accessed: Feb. 07, 2016.

FADINI, A. L.; QUEIROZ, M. B. Savory drageados manufacturing technology. ITAL, Campinas, p. 1-31, 2014 (apostila).

GAROTO. Calories and nutritional information from Garoto Chocolate. 2018. Available from: <https://www.fatsecret. com.br/calorias-nutri\% $\%$ C3\%A $7 \% \mathrm{C} 3 \% \mathrm{~A} 3 \mathrm{o} / \mathrm{search}$ ? $=$ Garoto + Chocolate>. Accessed: Jun. 16, 2018.

GESCHWINDNER, G,; DROUVEN, H. Manufacturing processes: chocolate panning and inclusions. In TALBOT, G. (Ed). Technology of coated and filled chocolate, confectionery and bakery produtcs. (pp. 397-412) Cornwall, UK: Blackwell Publishing, 2009.

GONI, I.; et al. Analysis of resistant starch: method for foods and food products. Food Chemistry. Saint Paul, v.56, n.4, p. 445-449, 1996.

HIRAYAMA, F. et al. Soy consumption and risk of COPD and respiratory symptoms: A case-control study in Japan. Respiratory Research, v.10, p.56, 2009. Available from: <http://dx.doi org/10.1186/1465-9921-10-56>. Accessed: May, 16, 2018. doi: $10.1186 / 1465-9921-10-56$.

HUANG, H. et al. Inhibitory activity and conformation changes of soybean trypsin inhibitors induced by ultrasound. Ultrasonics Sonochem. v.15, p.724-30, 2008. Available from: $<\mathrm{http}: / / \mathrm{dx}$. doi org/10.1016/j.ultsonch.2007.10.007>. Accessed: May, 6, 2018. doi: $10.1016 /$ j.ultsonch.2007.10.007.

ITO, C. et al. Characterisation of proanthocyanidins from black soybeans: Isolation and characterisation of proanthocyanidin oligomers from black soybean seed coats. Food Chemistry, v.141, p.2507-2512, 2014. Available from: <http://dx.doi.org/10.1016/j. foodchem.2013.05.039>. Accessed: May, 1, 2018. doi: 10.1016/j. foodchem.2013.05.039.

JEONG, W. H. et al. Establishment of new method for analysis of starch contents and varietal differences in soybean seeds. Breeding Science, v.60, p.160-163, 2010. Available from: $<$ http:// dx.doi.org/10.1270/jsbbs.60.160>. Accessed: May, 16, 2018. doi: 10.1270/jsbbs.60.160.

JOGIHALLI, P. et al. Physico-functional and antioxidant properties of sand-roasted chickpea (Cicer arietinum). Food
Chemistry, v.237, p.1124-1132, 2017. Available from: <http:// dx.doi.org/10.1016/j.foodchem.2017.06.069>. Accessed: Feb. 17, 2018. doi:10.1016/j.foodchem.2017.06.069.

LEE, J. H. et al. Characterization of anthocyanins in the black soybean (Glycine $\max$ L.) by HPLC-DAD-ESI/MS analysis. Food Chemistry, v.112, p.226-231, 2009.Available from: <http:// dx.doi.org/10.1016/j.foodchem.2008.05.056>. Accessed: May, 6, 2018. doi: 10.1016/j.foodchem.2008.05.056.

LEE, K. J. et al. Anthocyanin and isoflavone contents in korean black soybean landraces and their antioxidant activities. Plant Breeding and Biotechnology, v.4, p.441-452, 2016. Available from: <http://dx.doi.org/10.9787/PBB.2016.4.4.441>. Accessed: May, 16, 2018. doi: 10.9787/PBB.2016.4.4.441.

LI, Y. Q. et al. Inactivation of soybean lipoxygenase in soymilk by pulsed electric fields. Food Chemistry, v.109, p.408414 , 2008. Available from: <http://dx.doi.org/10.1016/j. foodchem.2008.01.001>. Accessed: May, 3, 2017. doi: 10.1016/j. foodchem.2008.01.001.

MERRILL, A. L.; WATT, B. K. Energy value of foods: basis and derivation. DC: United States Department of Agriculture, Washington, 1973.

MULINACI, N. et al. Effect of cooking on the anthocyanins, phenolic acids, glycoalkaloids, and resistant starch content in two pigmented cultivars of Solanum Tuberosun L. Journal of Agricultural and Food Chemistry, v. 56, p. 11830-11837, 2008. Available from: $<\mathrm{http}: / / \mathrm{dx}$.doi.org/10.1021/jf801521e $>$. Accessed: May, 16, 2018. doi: 10.1021/jf801521e.

OLIVEIRA, G. H. H. et al. Physical characterization of coffee after roasting and grinding. Semina: Ciências Agrárias, v.35, p.18131828, 2014. Available from: <http://dx.doi.org/10.5433/16790359.2014v35n4p1813>. Accessed: May, 16, 2018. doi: 10.5433/1679-0359.2014v35n4p1813.

PEREIRA, E. A.Dredged Foods. Oleos\& Gorduras Alimentos e Tecnologia, p. $28-32,2010$.

POLESI, L. F. Resistant Starch: Applications and Production Methods. B. CEPPA, v.29, p.211-222, 2011. Available from: $<$ http://dx.doi.org/10.5380/cep.v29i2.25486>. Accessed: May, 16, 2018. doi: 10.5380/cep.v29i2.25486.

REBHOLZ, C. M. et al. Effect of soybean protein on novel cardiovascular disease risk factors: a randomized controlled trial. European Journal of Clinical Nutrition, v.67, p.58-63, 2013. Available from: <http://dx.doi.org/10.1038/ejcn.2012.186> . Accessed: May, 2, 2018. doi: 10.1038/ejcn.2012.186.

SÁ, M. E. L. et al. Ways of consuming soy. Informativo Agropecuário, v. 27, n. 230, p. 41-46, 2006.

SHARMA, P.; GUJRAL, H. S. Effect of sand roasting and microwave cooking on antioxidant activity of barley. Food Reseach International, v.44, n.1, p.235-240, 2011. Available from: <http:// dx.doi.org/10.1016/j.foodres.2010.10.030>. Accessed: May, 16, 2018. doi: $10.1016 /$ j.foodres.2010.10.030.

SHI, X. et al. Flavor characteristic analysis of soymilk prepared by different soybean cultivars and establishment of evaluation method of soybean cultivars suitable for soymilk processing. Food Chemistry, v.185, p.422-429, 2015. Available from: <http:// 
dx.doi.org/10.1016/j.foodchem.2015.04.011>. Accessed: May, 15, 2018. doi: 10.1016/j.foodchem.2015.04.011.

SILVA, A. G. de M.; FERNANDES, K. F. Chemical composition and antinutrients present in raw and roasted chicha almonds (Sterculiastriata A. St. Hill \& Naudin). Revista de Nutrição, v.24, p.305-314, 2011. Available from: <http://dx.doi.org/10.1590/ S1415-52732011000200011>. Accessed: May, 14, 2018. doi: 10.1590/S1415-52732011000200011.

SYAMALADEVI, R. M. et al. Influence of water activity on thermal resistance of microorganisms in lowmoisture foods: a review. Comprehensive Reviews in Food Science and Food Safety, v.15, p.353-370, 2016. Available from: <http://dx.doi. org/10.1111/1541-4337.12190>. Accessed: May, 6, 2018. doi: $10.1111 / 1541-4337.12190$

STONE, H.; SIDEL, J. L. Sensory evaluation practices. 3. ed. New York: Academic Press. 2004. 408 p.

TEIXEIRA, L.N. et al.Comparison of methods for anthocyanin quantification. Ceres, v.55, n.4, p.297-304, 2008. Available from: $<$ http://www.ceres.ufv.br/ojs/index.php/ceres/article/view/3320>. Accessed: Jul. 13, 2019.
WANG, D. et al. Thermal characterization of the anthocyanins from black soybean (Glycine max L.) exposed to thermogravimetry. LWT - Food Science and Technology, v.55, p.645-649, 2014. Available from: <http://dx.doi.org/10.1016/j.lwt.2013.10.007>. Acessed: May, 16, 2018. doi: 10.1016/j.lwt.2013.10.007.

WANG, W.-D.; XU, S.-Y. Degradation kinetics of anthocyanins in blackberry juice and concentrate. Journal of Food Engineering, v.82,p.271-275, 2007. Available from: <http://dx.doi.org/10.1016/j. jfoodeng.2007.01.018>. Accessed: May, 16, 2018. doi: 10.1016/j. jfoodeng.2007.01.018.

XU, J. L.et al. Differences in the metabolic profiles and antioxidant activities of wild and cultivated black soybeans evaluated by correlation analysis. Food Research International, v.100, n.2, p.166-174, 2017. Available from: <http://dx.doi.org/10.1016/j. foodres.2017.08.026>. Accessed: Jan. 5, 2018. doi: 10.1016/j. foodres.2017.08.026

ZILIC, S. et al. Comparisons of phenolic compounds, isoflavones, antioxidant capacity and oxidative enzymes in yellow and black soybeans seed coat and dehulled bean. European Food Research and Technology, v.237, p.409-418, 2013. Available from: <http:// dx.doi.org/10.1007/s00217-013-2005-y>. Accessed: Sep. 26, 2017. doi: $10.1007 / \mathrm{s} 00217-013-2005-\mathrm{y}$. 